\title{
EVALUATION AND COMPARISON OF B2C E-COMMERCE INTENSITY IN EU MEMBER STATES
}

\author{
Hana Kunešová, Ludvík Eger
}

\section{Introduction}

Electronic commerce (e-commerce), as part of e-business, is still undergoing dynamic development and significantly affects the economic reality in EU member states. E-commerce relates to the development of information and communications technologies (ICT). It has gone through development stages (detailed below), and since 2010 (Schneider, 2015) has been in its current maturity stage in developed countries and the European Union (EU) (Qin et al., 2014, according to whom the maturity stage of e-commerce dates back to 2004). This paper aims to propose a tool for assessing and comparing the intensity of B2C e-commerce in EU member states. Regarding this goal, the authors deal with the following research questions: What is the position of individual EU member states in terms of the intensity of $\mathrm{B} 2 \mathrm{C}$ e-commerce? Is there a strong correlation between B2C e-commerce intensity and the level of economic development of EU member states? Is there a correlation between B2C e-commerce intensity and the length of the countries' EU membership?

In the first section of this paper, the terms e-commerce and $\mathrm{B} 2 \mathrm{C}$ e-commerce, as well as the developmental stages of B2C e-commerce are defined. These definitions are followed by an overview of the indicators used in measuring B2C e-commerce intensity in an economy and the so-called B2C e-commerce indices, which in recent years, have been created to capture an aggregate view of various aspects of B2C e-commerce. The empirical section of our study introduces criteria for assessing the intensity of B2C e-commerce in EU member states and the procedure for creating the B2C e-commerce intensity index, which will allow a comprehensive comparison of B2C e-commerce in EU member states based on the selected criteria. Method TOPSIS was used in designing the proposed index. The assessment criteria reflect the relevant publicly available data on the B2C e-commerce intensity in EU member states, which are quantified in the form of specific indicators. The output of the empirical section consists list of EU member states in terms of B2C e-commerce intensity, which consider all the selected assessment criteria. The application of the results of this study contributes to the development of the theory of e-commerce, as well as represents a practical contribution. Determining and comparing the positions of EU member states in terms of B2C e-commerce intensity allows us to identify countries that do not sufficiently utilize the potential of B2C e-commerce to increase their prosperity and achieve consumer utility. In the conclusion of this paper, the current research limitations are discussed along with a suggestion for further research.

\section{Theoretical Background of e-Commerce}

Over the course of its existence, e-commerce has become a phenomenon that has been defined in many ways (e.g. Ho et al., 2007; Qin et al., 2014; Reynolds, 2010; Schneider, 2015; Yadav et al., 2013). The development of ICT and its implementation in the sphere of e-commerce has led to more specific definitions. The fast growth of e-commerce has created the need to adopt a uniform and internationally accepted definition for statistical monitoring and measuring this new phenomenon in commerce. The analyses of scientific research into e-commerce (Ngai \& Wat, 2001; Wang \& Chen, 2010) suggest that the first studies (e.g. Treese \& Stewart, 1998) were published in specialized journals in the early 1990s. The rapid growth of electronic transactions in the second half of the 1990s and the need for statistical measuring required a precise, and for reasons 
of international comparison, an internationally acceptable definition of the term "electronic commerce" and its distinction from "electronic business" (e-business).

\subsection{Defining e-Commerce}

In 2009, the Organisation for Economic Co-operation and Development (OECD) published a revised definition, which is still used in OECD documents today: "E-commerce transactions are the sale or purchase of goods or services conducted over computer networks by methods specifically designed for the purpose of receiving or placing of orders; payment and delivery are not considered. Transactions can occur between enterprises, households, individuals, governments and other organisations. The definition includes orders made through web pages, extranet or EDI and excludes orders by telephone calls, fax or manually typed e-mail." (OECD, 2013b, p. 226). A similar definition of electronic commerce is that by Eurostat (2015). However, scientific sources indicate other definitions of e-commerce and define e-commerce in a narrower and broader sense.

Defining electronic commerce in the narrow and broad sense relates to activities that are included in e-commerce. For example, Lee (2012) states that, in the narrow sense of the phrase, e-commerce is the process of buying, selling, or exchanging products, services and information via telecommunications networks. In the broader sense, e-commerce also includes, apart from buying and selling products and services, servicing customers, collaborating with business partners, and conducting electronic transactions within an organization.

The narrow definition of e-commerce, per Turban et al. (2015, p. 7), means "using the Internet and intranets to purchase, sell, transport, or trade data, goods, or services." A broader concept is presented by Stallmann and Wegner $(2015$, p. 6$)$, according to whom e-commerce is "the sum of all digital commercial transactions between economic entities, conducted through the Internet, most of it being the sale of goods and services."

Issues with defining electronic commerce do not include only the varying scope of definitions used, but also the understanding of the relationship between e-commerce and e-business. In 2003, the OECD defined electronic business as "(automated) business processes (both intra- and inter-company) over computer mediated networks" (OECD, 2003, p. 4). This definition was also adopted by the EU (European Commission, 2010, p. 174). Using this definition, electronic business includes a range of activities, including electronic commerce. However, according to some professional sources, the definition of e-commerce is virtually identical to that of e-business (e.g., Xu \& Quaddus, 2010; Schneider, 2015).

The non-uniform approach to understanding electronic commerce also manifests itself in Czech professional literature. Machková (2009) uses the terms e-commerce and e-business synonymously, saying: "Typical of the second half of the 1990s was the growth in electronic commerce (e-commerce, e-business)." Suchánek (2012) and Machková, Černohlávková, Sato, Malý and Sedláček (2014), on the other hand, consistently distinguish between the terms e-commerce and e-business. In our study, we use the term e-commerce per the 2009 OECD definition (see above).

\subsection{Classification of e-Commerce}

$\mathrm{E}$-commerce is classified based on various criteria. The basic categories of classification of the entities involved include business-tobusiness (B2B) and B2C. Interactions between consumers mediated by a third party fall under the consumer-to-consumer (C2C) category; however, direct interaction between consumers, e.g., on social media networks, without the use of a third party, are referred to as peer-to-peer (P2P). A category that grew in significance later was consumer-to-business $(\mathrm{C} 2 \mathrm{~B})$, in which the impetus comes from consumers who place their demand, for example, on the Internet. The number of e-commerce categories has increased with the inclusion of government institutions that provide their services to other entities online, which has given rise to the categories G2B, G2C, G2G, B2G, and C2G (Waghmare, 2012). The inclusion of employees has led to the creation of other categories, e.g., B2E (Turban et al., 2015) or E2E, formed by employees using a company network - intranet (Chaffey, 2015). According to OECD data, approximately $90 \%$ of the value of e-commerce comprises B2B transactions and $10 \%$ of those transactions are of the $\mathrm{B} 2 \mathrm{C}, \mathrm{B} 2 \mathrm{G}$, and 
C2C variety (OECD, 2013a, p. 4). Further classification is, for example, based on the openness of the medium used (OECD, 1999b) or the degree of use of ICT (e.g., Suchánek, 2012; Tassabehji, 2003; Turban et al., 2015). From the geographical point of view, there is a distinction between local, national, crossborder (Gomez Herrera et al., 2014) and global e-commerce.

\subsection{Development of B2C e-Commerce}

Since the mid-1990s, B2C e-commerce has seen rapid development. The significant milestones in e-commerce include the launch of the first e-shops in 1995 (Amazon, eBay), the so-called dotcom crash in 2000 , and the huge increase in the sale of smartphones in 2013.

For example, Schneider (2015) defines B2C e-commerce in context with the development of online business in the USA and views it as a long-term process divided into three stages. The first stage was the period between 1995 and 2003; the second stage lasted between 2004 and 2009, and the third stage has been in progress since 2010 . The milestones between the individual stages are represented by the beginning of the rapid development of e-shops in the USA in 1995, termination of the second wave of investments in e-commerce and e-business in the USA in 2003 following the dotcom crash, and the parallel appearance of new factors in 2010, which had a significant impact on further development of B2C e-commerce.

Similarly, Qin et al. (2014) characterize the development of e-commerce during the period from 1995 to 2000 as a Phase of e-commerce based on the Internet. During this phase, B2C e-commerce went through the germination stage (1995-1997) and the innovation stage (1997-2000).

The period after 2000 is referred to by the authors as the stage of e-concept-based e-commerce, during which e-commerce experienced a crisis following the dotcom crash. In 2004, e-commerce entered its maturity stage, which has lasted to this day. Further, they claim that after 2004 e-commerce ceased to be a phenomenon confined to the USA and became a business model that has spread to an increasing number countries.

In the most recent period, since 2010 (Schneider, 2015), several new e-commerce models have rapidly become widespread: mobile commerce (m-commerce), social commerce (s-commerce), and the electronic sale of mobile apps, following the "App Store" model. The massive increase in the number of users of the social network Facebook and its use for $\mathrm{B} 2 \mathrm{C}$ e-commerce has given rise to the term f-commerce (Turban et al., 2015, p. 13). Social networks also represent a new phenomenon in e-commerce (Khan \& Sagar, 2015).

\section{Measuring $\mathrm{B} 2 \mathrm{C}$ e-Commerce}

Starting in 1999, an OECD task force dealt intensively with questions of how to measure e-commerce. Their task was to suggest an internationally accepted definition of electronic commerce and a set of indicators for measuring and comparing internationally electronic commerce and its economic and social impacts (OECD, 1999a). The basis for identifying e-commerce indicators was the S-curve, representing three stages in the life cycle of e-commerce (e-commerce readiness, e-commerce intensity, and e-commerce impact) and its measurement priorities. A different type of information is given priority in each stage of the life cycle of e-commerce. Some research studies (e.g., Chaffey, 2015; Gomez Herrera et al., 2014; Ho et al., 2007; Kartiwi \& MacGregor, 2007; Kshetri, 2007; Savrul et al., 2014; Sing et al., 2001; Spremic \& Hlupic, 2007; Zhu et al., 2003) search for factors supporting the development of B2C e-commerce or, on the other hand, representing obstacles in its development, and thus contribute to the development of the methodology of measuring e-commerce.

In this study, we focus on the second stage of B2C e-commerce, e-commerce intensity, which comes after e-commerce readiness, and is followed by the third stage, focused on the future, e-commerce impact. In the second stage, that is, e-commerce maturity, the intensity of the use of e-commerce is tracked, and the current question is: What effect does e-commerce have on the economy and society? (OECD, 1999a; OECD, 2011)

\subsection{Measuring B2C e-Commerce Intensity}

The use of $\mathrm{B} 2 \mathrm{C}$ e-commerce includes the intensity and growth of B2C e-commerce, the nature of transactions, the sellers' activities, the consumers' behaviour, and other aspects (see Tab. 1). Statistical tracking of the aspects listed 


\section{Tab. 1: Indicators of B2C e-commerce intensity and selected data sources}

\begin{tabular}{|c|c|}
\hline Indicators of B2C e-commerce intensity & $\begin{array}{l}\text { Selected data sources } \\
\text { (data published with varying periodicity) }\end{array}$ \\
\hline $\begin{array}{l}\text { Companies selling online. Individuals shopping } \\
\text { online. Turnover of B2C e-commerce. Average } \\
\text { value of an online order. Frequency of online } \\
\text { shopping. Structure of goods and services } \\
\text { sold online. Payment methods used. Ways of } \\
\text { delivering products. }\end{array}$ & $\begin{array}{l}\text { The Czech Statistical Office } \\
\text { The Eurostat database } \\
\text { Ecommerce Europe. } \\
\text { Worldpay. Global payments report. } \\
\text { Commercial and research organizations }\end{array}$ \\
\hline $\begin{array}{l}\text { Domestic and cross-border online purchases, } \\
\text { sales. }\end{array}$ & $\begin{array}{l}\text { The Czech Statistical Office } \\
\text { Eurostat database }\end{array}$ \\
\hline
\end{tabular}

above makes it possible to identify sectors, industries, and whole economies that do or do not use the possibilities of $\mathrm{B} 2 \mathrm{C}$ e-commerce.

Individual indicators measure only selected aspects of B2C e-commerce. For a comprehensive assessment of B2C e-commerce, the not only the choice of individual indicators, but also their aggregation into an overall indicator, which can express a global view of $\mathrm{B} 2 \mathrm{C}$ e-commerce based on the evaluation criteria, is important. The aggregate indicators of B2C e-commerce (referred to as indices in foreign sources) are relatively new. There are currently several B2C e-commerce indicators, each of which focuses on tracking B2C e-commerce from a different point of view, however, none of them indicates the intensity of B2C e-commerce and its use.

Since 2012, the ATKearney consulting company has been publishing "The Global Retail E-commerce Index" (ATKearney, 2013), which expresses the attractiveness of economies for investments in B2C e-commerce on a 100-point scale. In 2014, The Economist Intelligence Unit published "The G20 e-Trade Readiness Index" (The Economist Intelligence Unit, 2014), which expresses the conditions for engagement in cross-border B2C e-commerce in $\mathrm{G} 20$ countries. It is evident that it does not comprehensively compare the use of e-commerce in the area that we are concerned. Since 2015, the "The UNCTAD B2C E-commerce Index" (UNCTAD, 2016) has been published, which compares economies based on four criteria: the share of individuals using the Internet, the number of secure Internet servers per 1 million people, the share of individuals with a credit card, and the postal reliability score. This index allows us to compare economies in terms of their readiness for B2C e-commerce and to identify their strengths and weaknesses in this area. Apart from the indices listed, there is also "The Readiness Index Forrester," put forth by the Forrester Company (2016). This index assesses the conditions for the development of B2C e-commerce based on 25 indicators. It is available only for clients of Forrester, and information regarding its structure or values is not publicly accessible.

\subsection{Issues with Measuring B2C e-Commerce}

Although B2C e-commerce has been around for more than 20 years, measuring and statistically tracking it is still problematic. In the early stage of its existence, B2C e-commerce was difficult to measure and the statistical data obtained wasn't comparable, as there was neither a uniform definition of B2C e-commerce nor any methodology of how to measure it (cf. Hawk, 2004). Introducing an internationally acceptable definition of B2C e-commerce and development of a methodology to measure it have contributed to resolving the initial problems. However, the problem with the objectivity and accessibility of data on B2C e-commerce transactions provided by business entities continues to this day (mainly regarding revenues from online sales, the average value of an online purchase, the number of orders, the average value of an order, and others). However, the fewest problems concern the availability of data regarding the readiness of the economy for $\mathrm{B} 2 \mathrm{C}$ e-commerce.

Problems with measuring B2C e-commerce transactions are due to several factors, which include: a large number of companies engaged 
in $\mathrm{B} 2 \mathrm{C}$ e-commerce; the fact that a number of companies engage in both electronic and traditional (brick-and-mortar) sales, yet their records do not make a distinction between the two sales methods; the tight competition in the field of $\mathrm{B} 2 \mathrm{C}$ e-commerce, which leads to the concealment or distortion of data; the dynamic development of ICT and the resulting new trends in $\mathrm{B} 2 \mathrm{C}$ e-commerce; and lastly, the ongoing methodological issues with measuring B2C e-commerce.

A large obstacle in measuring B2C e-commerce objectively is competition, which was mentioned by the OECD in the 1990s (OECD, 1997) as an obstacle in gaining business data for measuring $\mathrm{B} 2 \mathrm{C}$ e-commerce, but it is mentioned by other professional sources as well. Gomez Herrera et al. (2014) point out that data on B2C e-commerce are generated mainly by private companies involved in online e-commerce; however, commercial interests stop them from publishing this data. Cardona et al. (2015) and similarly Duch-Brown and Martens (2015) point to the problem with statistical data on e-commerce in the EU. The problem with data availability also applies to the Czech economy (e.g., Hlavenka, 2011).

Measuring B2C e-commerce is also affected by methodological problems, e.g., different procedures in data collection, in measuring cross-border B2C e-commerce, or in measuring B2C e-commerce in multinational corporations (OECD, 2015). Some of these problems can be eliminated by international standards for tracking and measuring $\mathrm{B} 2 \mathrm{C}$ e-commerce. An example of such a standard is the Global Online Measurement Standard for E-commerce (GOMSEC), adhered to by the international association for B2C e-commerce, Ecommerce Europe, including its national associations, and other cooperating organizations (Ecommerce Europe, 2016). Among other things, GOMSEC has defined the categories of products and services included in B2C e-commerce (e.g., Media and entertainment, Fashion, Toys, Electronics, and others), and determined which items will be excluded from reports on B2C e-commerce (e.g., the sale of motor vehicles, real estate, stocks and bonds, and others).

Since January 1, 2008, the Czech Statistical Office has been using the NACE international classification, which has considered technological development and structural changes in the economy, and made it possible to compare the statistical data from the Czech Republic with those of the EU as well as globally (Czech Statistical Office, 2008). In recent years, data on the development of B2C e-commerce has also been published by Eurostat in connection with the goals of the Europe 2020 strategy. The OECD publishes statistical data for all e-commerce categories without the distinction of $\mathrm{B} 2 \mathrm{C}$ e-commerce. Information on selected $\mathrm{B} 2 \mathrm{C}$ e-commerce indicators, without an extensive time series, is published on a limited scale by various organizations (e.g., Ecommerce Foundation, Statista.com, Forrester, Boston Consulting Group), which provide the full versions of documents only to their members. In the Czech Republic, apart from the Czech Statistical Office, e-commerce is monitored mainly by e-commerce consulting companies APEK and ACOMWARE.

\section{Comparison of EU Member States in Terms of $\mathrm{B} 2 \mathrm{C} \mathrm{e}$-Commerce Intensity}

The goal of this study is to propose a tool for assessing and comparing the intensity of B2C e-commerce in EU member states and, in relation to this, answer the following research questions: What is the position of individual EU member states in terms of $\mathrm{B} 2 \mathrm{C}$ e-commerce intensity? Is there a strong correlation between B2C e-commerce intensity and the level of economic development of EU member states? Is there a correlation between $\mathrm{B} 2 \mathrm{C}$ e-commerce intensity and the length of the countries' EU membership?

\subsection{Method}

To assess and compare B2C e-commerce intensity in EU member states, method of multicriteria evaluation of alternatives, that fall into the category of multi-criteria decision analysis methods, was chosen. Methods of multi-criteria evaluation of alternatives allow the aggregation of partial evaluation based on selected criteria into an aggregate assessment, which considers all the assessment criteria. The multi-criteria evaluation of the alternatives used results in the compilation of an order of alternatives (EU member states) from "the best" to "the worst" alternative (Kunešová, 2016).

Multi-criteria decision analysis is both an approach and a set of techniques, with the aim of providing an overall ordering of options, 
from the most preferred to the least preferred option (Dinçer, 2011). Multi-criteria decision problems are characterized by a set of decision alternatives, a set of evaluation criteria, and a number of links between the criteria and the alternatives. The decision-maker inputs information on the alternatives and evaluation criteria, which helps to formulate the multicriteria model. Multi-criteria evaluation of alternatives makes it possible to assess a finite number of alternatives based on the finite number of criteria. The number of alternatives can range from several to thousands of alternatives. The alternatives are "screened, prioritized, selected and/or ranked" (Yoon \& Hwang, 1995, p. 2).

Crucial to the evaluation of alternatives is the choice of evaluation criteria, specifically, attributes according to which the alternatives are assessed. Yoon and Hwang $(1995$, p. 2) state that the number of evaluation criteria depends on the nature of the problem. The criteria must be independent, should cover all the evaluation attributes, should not be too many in number to avoid making the problem chaotic (Šubrt et al., 2015), and must be quantifiable. To resolve problems of multi-criteria evaluation of alternatives, it is important whether and how certain criteria are given preference.

In the study, the preference of criteria is expressed by criteria weights. Generally, criteria weights are values in the interval $\langle 0,1\rangle$, which express the relative importance of individual criteria in comparison with others. The sum of all criteria weights is equal to 1 . The greater the importance of a criterion, the bigger its weight. The relative importance of an individual criterion is expressed by the criteria weight vector (Fiala, 2013).

This study uses the point method, which is based on the supposition that the decisionmaker is able, not only to determine the order of criteria based on their importance, but also quantify the importance of each criterion by a number of points on a pre-selected scale. This method is suitable even for evaluation by multiple experts (Šubrt et al., 2015). The assigning of points to criteria by a larger number of experts (e.g., through questionnaires) increases the level of objectivity in determining criteria weights. The calculation of criteria weights (the normalization of weight vector values) from the point evaluation was done using the following formula:

$$
v_{i}=\frac{b_{j}}{\sum_{j=1}^{n} b_{j}}
$$

where $b_{j}$ is the sum of all points assigned by the individual experts to criterion $j$, and $j=1,2, \ldots, n$.

In our study we used the TOPSIS method (the Technique for Order of Preference by Similarity to Ideal Solution - TOPSIS), which was developed by Hwang and Yoon (1981) and represents methods based on the principle of minimization of the distance from the ideal solution and maximization of the distance from the negative-ideal solution. The TOPSIS method allows us to determine the order of all the alternative solutions. The required input data include cardinal information (the actual values of the alternatives based on individual criteria in different units) and individual criteria weights. The TOPSIS method evaluates the decision matrix which refers to $p$ alternatives which are evaluated in terms of $k$ criteria. The TOPSIS method consists of the following six steps (for example Dinçer, 2011; Fiala, 2013; Šubrt et al., 2015; Triantaphyllou et al., 1998).

\section{Step 1: Construct the normalized decision matrix}

This process tries to convert the various attribute dimensions into non-dimensional attributes. For the normalization of input values, the TOPSIS method uses an approach based on the Euclidean distance (formula 2). The element $r_{i j}$ of the normalized decision matrix $R$ can be calculated as follows:

$$
r_{i j}=\frac{y_{i j}}{\left[\sum_{i=1}^{p}\left(y_{i j}\right)^{2}\right]^{1 / 2}}
$$

where $y_{i j}$ is the input value of the $i$ alternative assessed by the $j$ criterion; $p$ is the number of alternatives, $i=1,2, \ldots . p, j=1,2, \ldots k$.

\section{Step 2: Construct the weighted normalized decision matrix}

The weighted normalized criteria matrix $W=\left(w_{i j}\right)$ is based on the normalized criteria matrix $R=\left(r_{i j}\right)$ in such a way that each element $r_{i j}$ of the $R$ matrix is multiplied by the appropriate weight $v_{j}$ (formula 3):

$$
w_{i j}=v_{j} r_{i j}
$$


where $v_{j}$ is the weight of criterion $j$, and $r_{i j}$ are the matrix elements of the normalized criteria matrix $\mathrm{R}$.

\section{Step 3: Determine the ideal and the negative- ideal solutions}

The elements of the matrix $\mathrm{W}$ determine the ideal solution $H_{j}$ with criteria values $\left(H_{1}, H_{2}\right.$, $\left.\ldots, H_{k}\right)$ and the negative-ideal solution $D_{j}$ with criteria values $\left(D_{1}, D_{2}, \ldots, D_{k}\right)$, given the values in the weighted criteria matrix $W$. The ideal solution delivers the best values based on each criterion; the negative-ideal solution delivers the worst values based on each criterion.

Step 4: Calculate the separation distances of each alternative to the ideal solution and the negative-ideal solution

$$
d_{i}^{+}=\sqrt{\sum_{j=1}^{k}\left(w_{i j}-H_{j}\right)^{2}}, i=1,2, \ldots, p
$$

where $d_{i}^{+}$is the separation (in the Euclidean sense) of each alternative from the ideal solution.

$$
d_{i}^{-}=\sqrt{\sum_{j=1}^{k}\left(w_{i j}-D_{j}\right)^{2}}, i=1,2, \ldots, p
$$

where $d_{\boldsymbol{i}}^{-}$is the separation (in the Euclidean sense) of each alternative from the non-ideal solution.

Step 5: Calculate the relative distances of each alternative from the negative-ideal solution

$$
c_{i}=\frac{d_{i}^{-}}{d_{i}^{+}+d_{i}^{-}}, i=1,2, \ldots, p
$$

where $c_{i}$ is the indicator of the relative distance of an alternative from the negative-ideal solution.

\section{Step 6: Rank the preference order}

Rank the alternatives, sorting them by the value of the indicator $c_{i}$, in decreasing order. The best alternative is the one that has the longest distance from the negative-ideal solution.

\subsection{Criteria for Evaluating B2C e-Commerce Intensity}

For the purpose of comparing EU member states in terms of B2C e-commerce intensity, two criteria were selected that relate to the engagement of consumers and sellers in B2C e-commerce, and one criterion that relate to commercial transactions within $\mathrm{B} 2 \mathrm{C}$ e-commerce (relative size of the turnover of $\mathrm{B} 2 \mathrm{C}$ e-commerce). Following research into the potential sources of data on the use of B2C e-commerce, the Eurostat database (2017) was chosen to provide statistical data for these criteria. Tab. 2 details the selected criteria, their quantification in the form of a specific indicator, and the data source. The study uses the latest data from the sources listed.

All the criteria in Tab. 2 are maximization criteria, i.e., the higher the value of the particular criterion, the better the result of the country in the area that is being evaluated. In connection with the above-mentioned criteria and selected method of multi-criteria evaluation of alternatives, the authors have suggested the following hypotheses:

H1: There is a strong correlation between the order of EU member states in terms of B2C e-commerce intensity and their order in terms of their economic development.

\section{Tab. 2: Criteria for evaluating B2C e-commerce intensity}

\begin{tabular}{c|l|l|c} 
Criterion No. & \multicolumn{1}{|c|}{ Criterion } & \multicolumn{1}{c|}{ Quantification of the criterion } & Data source \\
\hline 1 & $\begin{array}{l}\text { Internet purchases } \\
\text { by individuals }\end{array}$ & $\begin{array}{l}\text { The percentage of individuals (aged 16-74) } \\
\text { who made last online purchase in the past } \\
12 \text { months, data obtained in 2016 }\end{array}$ & Eurostat (2017) \\
\hline 2 & $\begin{array}{l}\text { Enterprises selling } \\
\text { via a website - B2C }\end{array}$ & $\begin{array}{l}\text { The share of enterprises that sold online } \\
\text { on the B2C market in 2016 (\% of enterprises } \\
\text { excluding those in the financial sector) }\end{array}$ & Eurostat (2017) \\
\hline 3 & $\begin{array}{l}\text { Relative size of the } \\
\text { enterprises' turnover } \\
\text { from web sales - B2C }\end{array}$ & $\begin{array}{l}\text { The share of the turnover from web sales } \\
- \text { B2C in the total turnover of enterprises } \\
\text { in 2016 (in \%) }\end{array}$ & Eurostat (2017) \\
\hline
\end{tabular}




\section{Tab. 3: The decision matrix for evaluating B2C e-commerce intensity}

\begin{tabular}{|c|c|c|c|}
\hline Criterion No. & 1 & 2 & 3 \\
\hline Type of criterion & $\max$. & $\max$. & $\max$. \\
\hline Period & 2016 & 2016 & 2016 \\
\hline Alternative / unit & $\%$ & $\%$ & $\%$ \\
\hline Austria & 58 & 12 & 1 \\
\hline Belgium & 57 & 17 & 3 \\
\hline Bulgaria & 17 & 6 & $0^{(\mathrm{n})}$ \\
\hline Croatia & 33 & 11 & 1 \\
\hline Cyprus & 29 & 12 & 1 \\
\hline Czech Republic & 47 & 17 & 2 \\
\hline Denmark & 82 & 15 & 2 \\
\hline Estonia & 56 & 12 & 2 \\
\hline Finland* & 67 & 13 & 2 \\
\hline France & 66 & 12 & 2 \\
\hline Germany & 74 & 18 & 1 \\
\hline Greece & 31 & 10 & 3 \\
\hline Hungary & 39 & 11 & 1 \\
\hline Ireland & 59 & 22 & 12 \\
\hline Italy* & 29 & 7 & $0^{(n)}$ \\
\hline Latvia & 44 & 7 & 1 \\
\hline Lithuania & 33 & 15 & 2 \\
\hline Luxembourg** & 78 & 8 & 3 \\
\hline Malta & 48 & 18 & 1 \\
\hline Netherlands & 74 & 14 & 3 \\
\hline Poland & 42 & 8 & 1 \\
\hline Portugal & 31 & 10 & 2 \\
\hline Romania & 12 & 4 & 1 \\
\hline Slovakia & 56 & 9 & 1 \\
\hline Slovenia & 40 & 12 & 1 \\
\hline Spain & 44 & 11 & 2 \\
\hline Sweden & 76 & 15 & 3 \\
\hline United Kingdom & 83 & 15 & 4 \\
\hline
\end{tabular}

Source: Eurostat (2017) and authors' own elaboration

Note: (n) not significant

* For countries marked with an asterisk, data for criterion 3 for the year 2016 were not available and the last known data were used instead (Finland: 2015, Italy: 2014).

** In the case of Luxembourg, there were no data for criterion 3 available for any year (according to Eurostat, data for Luxembourg are confidential). The missing value of criterion 3 for Luxembourg was set as the average of the values for criterion 3 of Belgium and the Netherlands (countries of the Benelux). 
H2: The highest B2C e-commerce intensity can be found in countries that have been members of the EU the longest.

H3: The lowest B2C e-commerce intensity can be found in new EU member states with low economic development.

The input data contained in Tab. 3 shows that none of the alternatives assessed are the best or worst in all criteria. Using the point method, a weight was assigned to each criterion, based on a questionnaire survey conducted among experts on $\mathrm{B} 2 \mathrm{C}$ e-commerce. The criteria weights are calculated according to formula (1). The points assigned by the experts and the calculation of criteria weights are shown in Tab. 4. The experts include representatives of three Czech universities, who have been engaging with the topic of online marketing and e-commerce for a long term (five years experience minimum), representatives of major companies, such as Google Czech Republic, ACOMWARE, MarketUP, and representatives of regional professional agencies that administer a number of e-shops, such as ANT Studio and PrOSEO Media, and finally representatives of e-shop owners. These experts make up a representative sample for the purpose of determining the weights of selected B2C e-commerce criteria.
The following text presents the output of the selected method of multi-criteria evaluation of alternatives that was applied to the selected evaluation criteria and their preference given by the criteria weights. All the calculations were performed in MS Excel.

\section{The Order of EU Member States Determined by the TOPSIS Method}

The decision matrix for evaluating B2C e-commerce intensity (Tab. 3) was converted according to the formula (2) to a normalized criteria matrix (Tab. 5).

Based on the normalized criteria matrix in Tab. 5 and the criteria weights (Tab. 4), the weighted criteria matrix was constructed according to the formula (3). Using its elements, the hypothetical negative-ideal solution $D_{j}$ was determined with the criteria values $\left(D_{1}, D_{2}, \ldots\right.$, $\left.D_{k}\right)$ and the hypothetical ideal solution $H_{j}$ with the criteria values $\left(H_{1}, H_{2}, \ldots, H_{k}\right)$ with respect to the values in the weighted criteria matrix. Using the formulas (4) and (5) for calculating the distance of individual alternatives from the ideal and negative-ideal solutions, the coefficient $d_{i}^{+}$ was determined, which expresses the distance of the alternative $i$ from the ideal solution, and the coefficient $d_{i}$, which expresses the distance of the alternative $i$ from the negative-ideal

\begin{tabular}{|c|c|c|c|}
\hline \multirow[t]{3}{*}{ Tab. 4: } & \multicolumn{3}{|c|}{$\begin{array}{l}\text { Determining criteria weights for evaluating B2C e-commerce intensity } \\
\text { by the point method }\end{array}$} \\
\hline & \multicolumn{3}{|c|}{ Criteria } \\
\hline & 1 & 2 & 3 \\
\hline Expert 1 & 9 & 8 & 8 \\
\hline Expert 2 & 5 & 8 & 5 \\
\hline Expert 3 & 7 & 8 & 6 \\
\hline Expert 4 & 10 & 7 & 10 \\
\hline Expert 5 & 7 & 6 & 9 \\
\hline Expert 6 & 10 & 9 & 8 \\
\hline Expert 7 & 10 & 10 & 8 \\
\hline Expert 8 & 9 & 5 & 10 \\
\hline Expert 9 & 4 & 3 & 3 \\
\hline Subtotal & 71 & 64 & 67 \\
\hline \multicolumn{4}{|c|}{ Total No. of points assigned: 202} \\
\hline Criterion weight & 0.351 & 0.317 & 0.332 \\
\hline
\end{tabular}




\section{Tab. 5: Normalized criteria matrix according to the TOPSIS method}

\begin{tabular}{l|l|l|l}
\multicolumn{1}{c|}{ Criterion No. } & $\mathbf{1}$ & $\mathbf{2}$ & $\mathbf{3}$ \\
\hline Austria & 0.2036 & 0.1766 & 0.0635 \\
\hline Belgium & 0.2001 & 0.2502 & 0.1905 \\
\hline Bulgaria & 0.0597 & 0.0883 & 0.0000 \\
\hline Croatia & 0.1159 & 0.1619 & 0.0635 \\
\hline Cyprus & 0.1018 & 0.1766 & 0.0635 \\
\hline Czech Republic & 0.1650 & 0.2502 & 0.1270 \\
\hline Denmark & 0.2879 & 0.2208 & 0.1270 \\
\hline Estonia & 0.1966 & 0.1766 & 0.1270 \\
\hline Finland & 0.2352 & 0.1913 & 0.1270 \\
\hline France & 0.2317 & 0.1766 & 0.1270 \\
\hline Germany & 0.2598 & 0.2649 & 0.0635 \\
\hline Greece & 0.1088 & 0.1472 & 0.1905 \\
\hline Hungary & 0.1369 & 0.1619 & 0.0635 \\
\hline Ireland & 0.2072 & 0.3238 & 0.7620 \\
\hline Italy & 0.1018 & 0.1030 & 0.0000 \\
\hline Latvia & 0.1545 & 0.1030 & 0.0635 \\
\hline Lithuania & 0.1159 & 0.2208 & 0.1270 \\
\hline Luxembourg & 0.2739 & 0.1177 & 0.1905 \\
\hline Malta & 0.1685 & 0.2649 & 0.0635 \\
\hline Netherlands & 0.2598 & 0.2060 & 0.1905 \\
\hline Poland & 0.1475 & 0.1177 & 0.0635 \\
\hline Portugal & 0.1088 & 0.1472 & 0.1270 \\
\hline Romania & 0.0421 & 0.0589 & 0.0635 \\
\hline Slovakia & 0.1966 & 0.1325 & 0.2540 \\
\hline Slovenia & 0.1404 & 0.1766 & \\
\hline Spain & 0.1545 & 0.1619 & 0.2208 \\
\hline Sweden & 0.2668 & 0.2208 & \\
\hline United Kingdom & 0.2914 & & 0.1905 \\
\hline & & & \\
\hline
\end{tabular}

solution. Using the formula (6) the indicator $c_{i}$ was calculated. The alternatives are arranged in a descending order, from the highest to the lowest values of the indicator $c_{i}$. This way, all the alternatives are ordered according to their relative distance from the hypothetical negativeideal solution (Tab. 6).

Next Tab. 7 shows the order of EU member states in terms of B2C e-commerce intensity determined by the TOPSIS method of multicriteria evaluation. The ordered list considers three selected evaluation criteria. Based on the similarity of the relative indicator of the distance of the alternatives from the negative-ideal solution, the EU member states were divided into clusters (see Tab. 7). The division of countries into clusters was carried out using the centroid clustering method (Klímek, 2008) and the appropriate software. Countries assigned to the same group are more similar to one another in terms of overall use of B2C e-commerce than countries assigned to other clusters. The 


\section{Tab. 6: Determining the order of alternatives according to the TOPSIS method}

\begin{tabular}{|c|c|c|c|c|}
\hline Alternatives & $d_{i}^{+}$ & $d_{i}$ & $c_{i}$ & $\begin{array}{c}\text { Order } \\
\text { of alternatives }\end{array}$ \\
\hline Austria & 0.2385 & 0.0711 & 0.2295 & 17 \\
\hline Belgium & 0.1938 & 0.1037 & 0.3485 & 5 \\
\hline Bulgaria & 0.2760 & 0.0112 & 0.0389 & 28 \\
\hline Croatia & 0.2454 & 0.0467 & 0.1599 & 23 \\
\hline Cyprus & 0.2457 & 0.0477 & 0.1626 & 22 \\
\hline Czech Republic & 0.2167 & 0.0855 & 0.2830 & 11 \\
\hline Denmark & 0.2133 & 0.1089 & 0.3379 & 7 \\
\hline Estonia & 0.2185 & 0.0782 & 0.2635 & 12 \\
\hline Finland & 0.2159 & 0.0902 & 0.2947 & 9 \\
\hline France & 0.2169 & 0.0872 & 0.2867 & 10 \\
\hline Germany & 0.2329 & 0.1027 & 0.3060 & 8 \\
\hline Greece & 0.2079 & 0.0730 & 0.2599 & 13 \\
\hline Hungary & 0.2436 & 0.0512 & 0.1736 & 21 \\
\hline Ireland & 0.0296 & 0.2728 & 0.9022 & 1 \\
\hline Italy & 0.2708 & 0.0252 & 0.0851 & 26 \\
\hline Latvia & 0.2470 & 0.0469 & 0.1595 & 24 \\
\hline Lithuania & 0.2221 & 0.0713 & 0.2430 & 15 \\
\hline Luxembourg & 0.2008 & 0.1047 & 0.3428 & 6 \\
\hline Malta & 0.2366 & 0.0817 & 0.2567 & 14 \\
\hline Netherlands & 0.1937 & 0.1096 & 0.3614 & 4 \\
\hline Poland & 0.2462 & 0.0465 & 0.1588 & 25 \\
\hline Portugal & 0.2273 & 0.0558 & 0.1970 & 19 \\
\hline Romania & 0.2617 & 0.0211 & 0.0746 & 27 \\
\hline Slovakia & 0.2420 & 0.0627 & 0.2057 & 18 \\
\hline Slovenia & 0.2424 & 0.0550 & 0.1850 & 20 \\
\hline Spain & 0.2222 & 0.0663 & 0.2299 & 16 \\
\hline Sweden & 0.1927 & 0.1134 & 0.3704 & 3 \\
\hline United Kingdom & 0.1718 & 0.1319 & 0.4343 & 2 \\
\hline
\end{tabular}

last two columns of Tab. 7 indicate the year of the country's accession to the European Union (or the European Community, or the European Economic Community) and the economic development of the country in the year 2016 expressed by GDP per capita in Purchasing Power Standards (PPS). This indicator is expressed in relation to the European Union (EU28) average set to equal 100.

\section{The Results of the TOPSIS Method: Comparison of B2C e-Commerce Intensity}

The results of the multi-criteria evaluation and the positions of individual countries in the overall order indicate that in terms of B2C e-commerce intensity, EU member states are a rather heterogeneous group. Among other things, this leads to the fact that only certain economies can use $\mathrm{B} 2 \mathrm{C}$ e-commerce for their 


\begin{tabular}{|c|c|c|c|c|c|}
\hline Tab. 7 & $\begin{array}{l}\text { The order of } \\
\text { on into clust }\end{array}$ & $\begin{array}{l}\text { Iternative } \\
\text { rs }\end{array}$ & terms of B2C & merce inte & and their divisi- \\
\hline Order & Alternative & $\begin{array}{c}\text { Indicator } \\
c_{i}\end{array}$ & $\begin{array}{c}\text { Clusters } \\
\text { and centroids }\end{array}$ & $\begin{array}{l}\text { Accession } \\
\text { to the EU }\end{array}$ & $\begin{array}{l}\text { GDP per capita } \\
\text { in PPS } 2016 \\
(E U 28=100)\end{array}$ \\
\hline 1 & Ireland & 0.9022 & $\begin{array}{c}\text { Cluster } 1 \\
\text { Centroid: } 0.9022\end{array}$ & 1973 & 177 \\
\hline 2 & United Kingdom & 0.4343 & \multirow{6}{*}{$\begin{array}{c}\text { Cluster } 2 \\
\text { Centroid: } 0.3659\end{array}$} & 1973 & 108 \\
\hline 3 & Sweden & 0.3704 & & 1995 & 124 \\
\hline 4 & Netherlands & 0.3614 & & 1958 & 128 \\
\hline 5 & Belgium & 0.3485 & & 1958 & 118 \\
\hline 6 & Luxembourg & 0.3428 & & 1958 & 267 \\
\hline 7 & Denmark & 0.3379 & & 1973 & 125 \\
\hline 8 & Germany & 0.3060 & \multirow{10}{*}{$\begin{array}{c}\text { Cluster } 3 \\
\text { Centroid: } 0.2653\end{array}$} & 1958 & 123 \\
\hline 9 & Finland & 0.2947 & & 1995 & 109 \\
\hline 10 & France & 0.2867 & & 1958 & 105 \\
\hline 11 & Czech Republic & 0.2830 & & 2004 & 88 \\
\hline 12 & Estonia & 0.2635 & & 2004 & 74 \\
\hline 13 & Greece & 0.2599 & & 1981 & 67 \\
\hline 14 & Malta & 0.2567 & & 2004 & 95 \\
\hline 15 & Lithuania & 0.2430 & & 2004 & 75 \\
\hline 16 & Spain & 0.2299 & & 1986 & 92 \\
\hline 17 & Austria & 0.2295 & & 1995 & 126 \\
\hline 18 & Slovakia & 0.2057 & \multirow{8}{*}{$\begin{array}{c}\text { Cluster } 4 \\
\text { Centroid: } 0.1753\end{array}$} & 2004 & 77 \\
\hline 19 & Portugal & 0.1970 & & 1986 & 77 \\
\hline 20 & Slovenia & 0.1850 & & 2004 & 83 \\
\hline 21 & Hungary & 0.1736 & & 2004 & 67 \\
\hline 22 & Cyprus & 0.1626 & & 2004 & 81 \\
\hline 23 & Croatia & 0.1599 & & 2013 & 59 \\
\hline 24 & Latvia & 0.1595 & & 2004 & 65 \\
\hline 25 & Poland & 0.1588 & & 2004 & 69 \\
\hline 26 & Italy & 0.0851 & \multirow{3}{*}{$\begin{array}{c}\text { Cluster } 5 \\
\text { Centroid: } 0.0662\end{array}$} & 1958 & 96 \\
\hline 27 & Romania & 0.0746 & & 2007 & 59 \\
\hline 28 & Bulgaria & 0.0389 & & 2007 & 48 \\
\hline
\end{tabular}

own growth and take advantage of the benefits that e-commerce offers to both vendors and consumers.

Intensive use of B2C e-commerce is found in Ireland, which significantly outperform all other EU member states. Ireland exhibits the highest share of turnover of B2C e-commerce in the overall turnover of businesses and the highest share of businesses with online sales in the B2C market (see Tab. 3). Ireland is followed, after a large gap, by highly developed economies of Northern and Western Europe, which form a relatively homogenous group concentrated in cluster 2 . The high engagement of the population of Great Britain in online shopping, together with the large turnover of 
Amazon and other online retailers (e.g., Tesco and Sainsbury's) puts Great Britain in a leading position in this group.

The third group includes EU member states with an average and slightly belowaverage $\mathrm{B} 2 \mathrm{C}$ e-commerce intensity. This group also includes the Czech Republic, which took the eleventh place on the list. This cluster includes highly developed economies (Austria, Germany, Finland, France), as well as countries with significantly lower economic level (e.g. Estonia and Greece).

The EU member states in clusters 4 and 5 are engaged very little in B2C e-commerce. A problematic situation is especially in Bulgaria, Romania and Italy.

The correlation between the order of countries in terms of B2C e-commerce intensity and in terms of their economic development is calculated using the Spearman Rank Correlation Coefficient according to the formula (7) with correction for tied ranks (Neubauer et al., 2016, p. 240):

$$
r_{S}=1-\frac{6 \sum_{i=1}^{n} d_{i}^{2}}{n\left(n^{2}-1\right)-n_{x}-n_{y}}
$$

where $r_{s}$ is the value of the Spearman Coefficient, $d_{i}$ is the difference in paired ranks, $n$ is the number of cases, $n_{x}$ and $n_{y}$ are the correction factors for the variables $x$ and $y$, respectively, when tied ranks occur (i.e., two or more cases receive the same rank on the same variable):

$$
\begin{aligned}
& n_{x}=\frac{1}{2} \sum_{j=1}^{r}\left(n_{x, j}^{3}-n_{x, j}\right) \\
& n_{y}=\frac{1}{2} \sum_{k=1}^{s}\left(n_{y, k}^{3}-n_{y, k}\right)
\end{aligned}
$$

where $r$ is the number of groupings of different tied ranks and $n_{x^{\prime} j}$ is the number of tied ranks in the $j$-th grouping, $s$ is the number of grouping of different tied ranks and $n_{y^{\prime} k}$ is the number of tied ranks in the $k$-th grouping.

The Spearman Coefficient, $r_{s}$, can take values from +1 to -1 . A $r_{s}$ of +1 indicates a perfect association of ranks, a $r_{s}$ of zero indicates no association between ranks and a $r_{s}$ of -1 indicates a perfect negative association of ranks.

The calculated value of the Spearman Coefficient is 0.7844 . This demonstrates a strong and statistically significant correlation between the two rankings (the critical value of Spearman's coefficient for a two-tailed test, $\mathrm{n}=28$ and significance level $\alpha=0.05$ is 0.3749 ). The $\mathrm{H} 1$ hypothesis was thus confirmed. The level of economic development appears to be a significant factor in $\mathrm{B} 2 \mathrm{C}$ e-commerce intensity; however, it does not sufficiently explain the differences in $\mathrm{B} 2 \mathrm{C}$ e-commerce intensity in the various EU states (see Tab. 7).

The data in Tab. 7 suggest not a strong correlation between the order of countries in terms of B2C e-commerce intensity and the length of their EU membership. Tab. 7 shows that $\mathrm{B} 2 \mathrm{C}$ e-commerce intensity is not highest in countries with the longest duration of EU membership, therefore Hypothesis 2 is not confirmed. The Spearman Coefficient was also used to determine the correlation between the order of the countries in terms of B2C e-commerce intensity and their order in terms of the length of their EU membership. In this case, its value, calculated using the formula (7) and the data in Tab. 7 , is 0.6596 , which indicates a moderate and statistically significant correlation of the said rankings.

\section{Conclusions and Research Limitations}

An overall view of the evaluation criteria provides clear information on the $\mathrm{B} 2 \mathrm{C}$ e-commerce intensity in EU member states. The order of countries based on the value of the aggregate indicator and the differences between countries suggest that currently there is a large unused potential of $\mathrm{B} 2 \mathrm{C}$ e-commerce in the $\mathrm{EU}$, not only in countries with weaker economies, but also in highly developed countries. The differences in the level of economic development of the countries do not sufficiently explain the differences in the intensity of B2C e-commerce. The order of countries also suggests a likely link between the $\mathrm{B} 2 \mathrm{C}$ e-commerce intensity and other factors. The low B2C e-commerce intensity in the southern part of the EU indicates a possible influence of other factors: for example, the countries' geographical location and the low B2C e-commerce intensity in neighbouring countries (see Ho et al., 2007). On the contrary, linguistic proximity with another country (e.g., in English- or German-speaking EU member states) presents an advantage of cross-border e-commerce and results in higher B2C e-commerce intensity.

With respect to factors influencing $\mathrm{B} 2 \mathrm{C}$ e-commerce, it is obvious that $\mathrm{B} 2 \mathrm{C}$ e-commerce 
relates to ICT development itself (Qin et al., 2014; Schneider, 2015; Shih, 2010) and the implementation of new ICT in the economies of EU member states (see the position of countries according to the ICT Development Index 2015 (ITU, 2016)). The development of B2C e-commerce is also narrowly connected with innovation activities in the commercial sector, which for a number of years have been co-financed from the EU structural funds, and also with creating an integrated EU market, harmonizing the relevant legislation, including consumer protection, etc. Still, the correlation between the order of countries in terms of B2C e-commerce intensity and in terms of the length of their EU membership is not very strong. It would be beneficial for further research to focus on the question of which factors have boosted the relatively high use of $\mathrm{B} 2 \mathrm{C}$ e-commerce in some new EU member states with lower level of economic development (Estonia and Lithuania) and what obstacles prevent more intensive use of B2C e-commerce in Italy and Austria, whose level of economic development significantly exceeds that of the aforementioned countries.

Research limitations are driven mainly by the limited availability of relevant data regarding the use of B2C e-commerce and missing or insufficient methodology of data supplied by private companies.

Our study of B2C e-commerce significantly enhances an understanding of this area and complements the above-mentioned and otherwise focused indices of ATKearney (2013) and UNCTAD (2016) with a B2C e-commerce intensity index created from three selected evaluation criteria using method of multi-criteria evaluation of alternatives (TOPSIS). Further research may focus on refining this index, if, for example, the methodology for defining e-commerce is elaborated in more detail, and more internationally comparable data in this segment become available. It is also apparent that further ICT development, as well as the development of new forms of e-commerce and online marketing will have an impact on the subsequent analysis and comparison of B2C e-commerce.

\section{References}

ATKearney. (2013). Global Retail E-Commerce Index ${ }^{\mathrm{TM}}$. Retrieved October 2, 2016, from http://www.southeast-asia.atkearney.com/ consumer-products-retail/e-commerce-index.
Chaffey, D. (2015). Digital business and e-commerce management (6th ed.). London, England: Pearson Education.

Cardona, M., Duch-Brown, N., Francois, J., Martens, B., \& Yang, F. (2015). The macroeconomic impact of e-commerce in the EU digital single market [Working Paper, 9, JRC98272]. Institute for Prospective Technological Studies Digital Economy. Retrieved June 3, 2016, from https://ec.europa.eu/jrc/sites/jrcsh/files/ JRC98272.pdf.

Czech Statistical Office. (2008). Klasifikace ekonomických činností (CZ-NACE). Retrieved June 8, 2016, from https://www.czso.cz/csu/ czso/klasifikace_ekonomickych_cinnosti_cz_nace.

Dinçer, S. E. (2011). Multi-criteria Analysis of Economic Activity for European Union Member States and Candidate Countries: TOPSIS and SWA Applications. European Journal of Social Sciences, 21(4), 563-572.

Duch-Brown, N., Grzybowski, L., \& Verboven, F. (2015). The impact of online sales on consumers and firms: Evidence from household appliances [Working Paper, 15, JR98079]. Institute for Prospective Technological Studies Digital Economy. Retrieved July 27, 2016, from https://ec.europa. eu/jrc/sites/jrcsh/files/JRC98079.pdf.

European Union. (2017). Countries. Retrieved April 5, 2017, from https://europa.eu/ european-union/about-eu/countries_en.

Eurostat. (2015). Glosary: E-commerce. Retrieved June 7, 2015, from http://ec.europa. eu/eurostat/statistics-explained/index.php/ Glossary:E-commerce.

Eurostat. (2017). Statistical Database. Retrieved August 31, 2017, from http:// ec.europa.eu/eurostat/data/database.

European Commission. (2010). ICT and e-Business for an Innovative and Sustainable Economy. 7th Synthesis Report of the Sectoral e-Business Watch. Retrieved July 10, 2015, from http://www.aimme.es/archivosbd/observatorio_ oportunidades/ICT_and_e-busuness_for_an.pdf.

Fiala, P. (2013). Modely a metody rozhodování (3rd ed.). Praha, Czech Republic: Oeconomica.

Forrester. (2016). Forrester Readiness Index: eCommerce 2015. Retrieved August 8, 2016, from https://www.forrester.com/report/Fo rrester+Readiness+Index+eCommerce+2015//E-RES131056.

Hawk, S. (2004). Comparison of B2C e-commerce in development countries. 
Electronic Commerce Research, 4(3), 181-199. doi:10.1023/B:ELEC.0000027979.91972.36.

Hlavenka, J. (2011). Rozmarné léto v elektronické komerci. Lupa.cz: Server o českém internetu. Retrieved September 10, 2016, from http://www.lupa.cz/clanky/ rozmarne-leto-v-elektronicke-komerci/.

Ho, Ch-S., Kauffman, J. R., \& Liang, P-T. (2007). A growth theory perspective on B2C e-commerce growth in Europe: An exploratory study. Electronic Commerce Research and Applications, 6(3), 237-259. doi:10.1016/j. elerap.2006.06.003.

Hwang, C.-L., \& Yoon, K. (1981). Multiple attribute decision making: Methods and applications, A state of the art survey. Berlin, Germany: Springer-Verlag.

Gomez Herrera, M. E., Martens, B., \& Turlea, G. (2014). The drivers and impediments for cross-border e-commerce in the EU. Information Economics and Policy, 28, 83-96. doi:10.1016/j.infoecopol.2014.05.002.

ITU. (2016). ICT Development Index 2015. Retrieved July 12, 2016, from http://www.itu.int/ net4/ITU-D/idi/2015/.

Kartiwi, M., \& MacGregor, C. R. (2007). Electronic Commerce Adoptions Barriers in Small to Medium Sized Enterprises (SMEs) in Developed and Developing Countries: A CrossCountry Comparison. Journal of Electronic Commerce in Organisations, 5(3), 35-51. doi:10.4018/jeco.2007070103.

Khan, M. A., \& Sagar, P. (2015). Emerging trends and advanced SWOT analysis of e-commerce in Indian context. International Journal of Science Technology \& Management, 4(Special Issue 2), 150-159.

Klímek, P. (2008). Shlukovací metody v data miningu. E\&M Ekonomie a Management, 11(2), 120-126.

Kunešová, H. (2016). Multi-criteria analysis of the involvement of European Union member states in B2C e-commerce. In E. Kovářová, L. Melecký, \& M. Staníčková (Eds.), Proceedings of the 3rd International Conference on European Integration 2016 (pp. 536-545). Ostrava, Czech Republic: VŠB - Technical University of Ostrava.

Kshetri, N. (2007). Barriers to e-commerce and competitive business models in developing countries: A case study. Electronic Commerce Research and Applications, 6(4), 443-452. doi:10.1016/j.elerap.2007.02.004.

Lee, I. (2012). Electronic commerce management for business activities and global enterprises: competitive advantages. Hershey, PA: Business Science Reference.

Machková, H. (2009). Mezinárodní marketing (3rd ed.). Praha, Czech Republic: Grada Publishing.

Machková, H., Černohlávková, E., Sato, A., Malý, J., \& Sedláček, J. (2014). Mezinárodní obchodní operace (6th ed.). Praha, Czech Republic: Grada Publishing.

Neubauer, J., Sedlačík, M., \& Kříž, O. (2016). Základy statistiky: aplikace $v$ technických a ekonomických oborech (2nd ed.). Praha, Czech Republic: Grada Publishing.

Ngai, E. W. T., \& Wat, K. K. T. (2002). A literature review and classification of electronic commerce research. Information \& Management, 39(5), 415-429. doi:10.1016/ S0378-7206(01)00107-0.

OECD. (1997). Measuring Electronic Commerce. OECD Digital Economy Papers, No. 27. doi:10.1787/237203566348.

OECD. (1999a). Defining and measuring e-commerce: A status report. OECD Working Party on Indicators for the Information Society [DSTI/ICCP/IIS(99)4/FINAL]. Retrieved September 23, 2016, from http://www.oecd.org/ sti/ieconomy/2092477.pdf.

OECD. (1999b). Economic and social impact of ecommerce: Preliminary findings and research agenda. OECD Digital Economy Papers, No. 40. doi:10.1787/236588526334.

OECD. (2003). 18th Meeting of the Voorburg Group on Service Statistics. Tokyo, October 2003. OECD work on standards for measuring electronic business. Retrieved October 25, 2016, from http://www4.statcan.ca/ english/voorburg/Documents/2003\%20tokyo/ papers/2003-098.pdf.

OECD. (2011). Guide to measuring the information society 2011. Retrieved October 25, 2016, from www.oecd.org/sti/measuringinfoeconomy/guide.

OECD. (2013a). Electronic and Mobile Commerce. OECD Digital Economy Papers, No. 228. doi:10.1787/5k437p2gxw6g-en.

OECD. (2013b). OECD Science, Technology and Industry Scoreboard 2013: Innovation for Growth. doi:10.1787/sti_scoreboard-2013-en.

OECD. (2015). OECD Science, Technology and Industry Scoreboard 2015: Innovation for growth and society. doi:10.1787/sti_scoreboard-2015-en.

Reynolds, J. (2010). E-Business. A Management Perspective. Oxford, England: Oxford University Press. 
Qin, Z., Chang, Y., Li, S., \& Li, F. (2014). E-commerce strategy. Berlin, Germany: Springer.

Schneider, G. P. (2015). Electronic Commerce (11th ed.). Stamford, CT: CENGAGE Learning.

Savrul, M., Incekara, A., \& Sener, S. (2014). The Potential of E-commerce for SMEs in a Globalizing Business Environment. Procedia - Social and Behavioral Sciences. 150, 35-45. doi:10.1016/j.sbspro.2014.09.005.

Shih, C. (2010). The Facebook era: Tapping online social networks to market, sell, and innovate. Boston, MA: Pearson Education.

Sing, T., Jayashankar, V. J., \& Singh, J. (2001). E-Commerce in the U.S. and Europe - Is Europe Ready to Compete? Business Horizons. 44(2), 6-16. doi:10.1016/S00076813(01)80017-3.

Spremic, M., \& Hlupic, V. (2007). Development of ecommerce in Croatia: A survey. Information Technology for Development. 13(4), 391-409. doi:10.1002/itdj.20068.

Stallmann, F., \& Wegner, U. (2015). Internationalisierung von E-CommerceGeschäften: Bausteine, Strategien, Umsetzung. Wiesbaden, Germany: Springer Gabler.

Suchánek, P. (2012). E-commerce: Elektronické podnikání a koncepce elektronického obchodování. Praha, Czech Republic: Ekopress.

Šubrt, T., Bartoška, J., Brožová, H., Dömeová, L., Houška, M., \& Kučera, P. (2015). Ekonomicko-matematické metody (2nd ed.). Plzeň, Czech Republic: Aleš Čeněk.

Tassabehji, R. (2003). Applying E-Commerce in Business. London, England: SAGE Publications.

The Economist Intelligence Unit. (2014). The G20 e-Trade Readiness Index. Retrieved August 2, 2016, from http://www. ebaymainstreet.com/sites/default/files/G20etrade-Readiness-Index.PDF.

Treese, G. W., \& Stewart, L. C. (1998). Designing Systems for Internet Commerce. Boston, MA: Pearson Education.

Triantaphyllou, E., Shu, B., Sanchez, S. N., \& Ray, T. (1998). Multi-Criteria Decision Making: An Operations Research Approach. In J. G. Webster (Ed.), Encyclopedia of Electrical and Electronics Engineering, 15 (pp. 175-186). New York, NY: John Wiley \& Sons.

Turban, F., King, D., Lee, J. K., Liang, T., \& Turban, D. C. (2015). Electronic commerce. A managerial and social networks perspective (8th ed.). Heidelberg, Germany: Springer.
UNCTAD. (2016). UNCTAD B2C e-commerce Index 2016: UNCTAD Technical Notes on ICT for Development $N^{\circ} 7$. Retrieved August 28, 2016, from http://unctad.org/en/ PublicationsLibrary/tn_unctad_ict4d07_en.pdf.

Wang, Ch-Ch., \& Chen, Ch-Ch. (2010). Electronic commerce research in latest decade: A literature review. International Journal of Electronic Commerce Studies, 1(1), 1-14. doi:10.7903/ijecs.898.

Waghmare, G. T. (2012). E-commerce; A business review and future prospects in Indian business. Indian Streams Research Journal, 2(4).

Xu, J., \& Quaddus, M. (2010). Foundation of e-business and e-business technologies. In J. Xu, \& M. Quaddus (Eds.), E-business in the 21st century: Realities, Challenges and Outlook (pp. 3-34). Singapore: World Scientific Publishing. Retrieved June 10, 2016 from http://www.worldscientific.com/ worldscibooks/10.1142/7097.

Yadav, S. M., de Valck, K., HenningThurau, T., Hoffman, D., \& Spann, M. (2013). Social Commerce: A Contingency Framework for Accessing Marketing Potential. Journal of Interactive Marketing, 27(4), 311-323. doi:10.1016/j.intmar.2013.09.001.

Yoon, K. P., \& Hwang, C. L (1995). Multiple Attribute Decision Making: An Introduction. Thousand Oaks, CA: SAGE Publications.

Zhu, K., Kraemer, K., \& Xu, S. (2003). Electronic business adoption by European firms, across-country assessment of the facilitators and inhibitors. European Journal of Information Systems. 12(4), 251-268. doi:10.1057/palgrave.ejis.3000475.

Ing. Hana Kunešová University of West Bohemia Faculty of Economics

Department of Marketing, Trade and Services kunesova@kmo.zcu.cz

doc. PaedDr. Ludvík Eger, CSc. University of West Bohemia Faculty of Economics Department of Marketing, Trade and Services leger@kmo.zcu.cz 


\title{
Abstract
}

\section{EVALUATION AND COMPARISON OF B2C E-COMMERCE INTENSITY IN EU MEMBER STATES}

\author{
Hana Kunešová, Ludvík Eger
}

Electronic commerce in the business-to-consumer sphere (B2C e-commerce) represents a significant factor in the competitiveness of companies and entire economies. The purpose of this paper is to propose a tool to evaluate and compare B2C e-commerce intensity in economies. The authors address the following research questions: What is the position of individual EU member states in terms of B2C e-commerce intensity? Is there a strong correlation between $\mathrm{B} 2 \mathrm{C}$ e-commerce intensity and the level of economic development of EU member states? Is there a correlation between $\mathrm{B} 2 \mathrm{C}$ e-commerce intensity and the length of the countries' $E U$ membership?

From a theoretical background, key indicators of B2C e-commerce intensity are selected, which are aggregated into the B2C e-commerce intensity index using the TOPSIS method. The results of the multi-criteria evaluation and the positions of individual countries in the overall order indicate that in terms of $\mathrm{B} 2 \mathrm{C}$ e-commerce intensity, EU member states are a rather heterogeneous group. The order of countries based on the value of the $\mathrm{B} 2 \mathrm{C}$ e-commerce intensity index exhibits a strong and statistically significant correlation with the order of the countries in terms of the level of their economic development. However, the differences in the countries' economic development do not sufficiently explain the differences in the use of $\mathrm{B} 2 \mathrm{C}$ e-commerce. The results indicate that there is a large unused potential of $\mathrm{B} 2 \mathrm{C}$ e-commerce in the $\mathrm{EU}$, not only in countries with weaker economies, but also in highly developed countries. The correlation between $\mathrm{B} 2 \mathrm{C}$ e-commerce intensity and the duration of EU membership is moderate. It would be beneficial for further research to focus on the question of which factors have boosted the relatively high use of B2C e-commerce in some new EU member states with lower level of economic development (Estonia and Lithuania) and what obstacles prevent more intensive use of B2C e-commerce in Italy and Austria, whose level of economic development significantly exceeds that of the aforementioned countries.

Key Words: B2C e-commerce, e-commerce intensity index, European Union, multi-criteria decision analysis, TOPSIS.

JEL Classification: L81, M21, C44.

DOI: 10.15240/tul/001/2017-4-011 